\title{
HAIR TYPES IN POLISH SELECTED TAXA OF POTENTILLA SUBSECT. COLLINAE (ROSACEAE)
}

\author{
JEREMI KOŁODZIEJEK \\ Department of Geobotany and Plant Ecology, University of Łódź \\ Banacha 12/16, 90-237 Łódź, Poland \\ e-mail: kolo@biol.uni.lodz.pl
}

(Received: April 17, 2007. Accepted: November 8, 2007)

\begin{abstract}
Leaf hair types in Polish selected taxa from Potentilla subsect. Collinae Juz., i.e. P. collina Wibel s.str., $P$. silesiaca Uechtr. P. thyrsiflora Hülsen ex Zimmeter, P. wimanniana Günther and Schummel, P. leucopolitana P.J. Müller and $P$. leucopolitana P.J. Müller $\times P$. incana P. Graebner were studied. A total of five unicellular hair types could be distinguished, based on the structure of the hair: straight, involuted, crispate, curved and stellate. The occurrence of involuted, curved and stellate hairs was observed for the first time for the majority of investigated taxa. There is a variation in density, position, as well as in the number of arms of stellate hairs. Although they are difficult to see without a stereo microscope, these differences seem to be systematically important. The study of hair types on surfaces of leaves supports the opinion that $P$. collina s.lato is a hybrid between $P$. argentea L. s.lato, $P$. tabernaemontani Ascherson and P. incana P. Gaertner. Hairs form consistent characters which are highly suited for systematic purposes. The key to Polish taxa based on leaf hair types is given as well.
\end{abstract}

KEY WORDS: hair types, SEM, Potentilla subsect. Collinae, identification key.

\section{INTRODUCTION}

According to literature, Potentilla sect. Terminales (Döll) Gren. and Godr. subsect. Collinae Juz. includes 19 taxa. The most of them (14 taxa) grow in Europe, i.e. P. alpicola De la Soie, $P$. alsatica T. Gregor, $P$. argenteiformis Kauffm., $P$. aspegrenii Kurtto, $P$. collina Wibel, $P$. johanniniana Goiran, $P$. leucopolitana $\mathrm{P}$. J. Müller, $P$. lindackeri Tausch, $P$. praecox F. W. Schultz, $P$. rhenana $\mathrm{P}$. J. Müller ex Zimmeter, $P$. silesiaca Uechtr., $P$. thyrsiflora Hülsen ex Zimmeter, $P$. wimanniana Günther and Schummel and $P$. wismariensis T. Gregor and Henker. Remaining five taxa are found in Asia Minor, i.e. P. armeniaca Siegfr., P. lazica Boiss. and Bal., P. sommieri Siegfr. and Kell., P. svanetica Siegfr. and Kell. and $P$. radiata Lehm.

In Poland five taxa of the $P$. subsect. Collinae have been identified, i.e. $P$. collina, $P$. thyrsiflora, $P$. silesiaca, $P$. wimanniana and $P$. leucopolitana (Wolf 1908; Szafer and Pawłowski 1955; Mirek et al. 2002; Gerstberger 2002; Kurtto et al. 2004). The occurence of $P$. silesiaca in Poland has not been seen in more than 100 years. Probably extinct in Poland already in the 19th century (Kołodziejek unpbl.).

It is stated in the literature that a characteristic feature for taxa from Potentilla subsect. Collinae is the presence of long appressed hairs on the underside of leaves. Furthermore, in taxa such as $P$. collina Wibel (= $P$. collina s.str.) and $P$. silesiaca Uechtritz imperfectly developed stellate hairs consist of up to 5-7 not identically long arms may be found which were described by Wolf (1908) as "Zackenhaare".
Features which distinguish the taxa of $P$. subsect. Collinae from other related ones, such as $P$. argentea L. s.lato, $P$. tabernaemontani Ascherson and $P$. incana P. Gaertner, are a different shape of styles as well as different kinds of hairs.

The kinds of hairs and their location have been, and still are, decisive for definition and delimitation of taxa in many parts of the genus. This is especially the case within the complicated $P$. collina and related groups.

The early descriptions of taxa in $P$. subsect. Collinae emphasized the presence of a "tomentum" on the leaves, but did not go into further detail. Therefore, the purpose of this paper is to describe the variation in hair types and their distribution within 5 taxa from $P$. subsect. Collinae, which occur in, or were reported from, Poland, i.e. $P$. collina $\mathrm{Wi}-$ bel, $P$. leucopolitana P.J. Müller, $P$. silesiaca Uechtr., $P$. thyrsiflora Hülsen ex Zimmeter and $P$. wimanniana Günther and Schummel. I have also examined hair types of $P$. leucopolitana $\times P$. incana. It is very similar to $P$. leucopolitana, Potentilla incana, $P$. Xsubarenaria and difficult to distinguished from this taxa.

\section{MATERIALS AND METHODS}

The material was obtained from herbarium sheets originating from herbaria: LE, PRA and BP - for abbreviations see Holmgren et al. 1990 except $P$. leucopolitana $\times P$. incana which came from natural habitat in Poland. Basal leaves 
from herbarium material were rehydrated by boiling in water and detergent. Two small pieces of leaves were cut from the lateral, right leaflet and subjected to critical point drying. The leaf pieces, representing the upper and lower leaf surface, were mounted and coated with gold, examined and photographed using a Tesla BS 340 scanning electron microscope. The hair types were analyzed on 5 photographs for each taxon. Morphometric analysis of the stellate hairs was made in a scanning electron microscope with micrometer scale (graduated to $0.01 \mu \mathrm{m}$ ). At least 30 individual stellate hairs was analyzed for each taxon. Nomenclature of taxa was used according to Wolf (1908) and Kurtto et al. (2004).

\section{RESULTS}

Hairs in the examined taxa of $P$. subsect. Collinae can be divided into five groups: straight, involuted, curved, stella- te, flexuose and crispate (Table 1). The latter usually form a tomentum on the lower leaf surface. All hair types can be found simultaneously on a single plant. The different hair types are illustrated in Figs 1-8 and descriptions are given below.

\section{Straight hairs (Fig. 1A)}

Straight hairs are unicellular hairs and vary in length from $50 \mu \mathrm{m}$ to $1.5 \mathrm{~mm}$. They are appressed to the surface. Straight hairs commonly occur on leaves of the majority of examined taxa, sometimes as the dominating pubescence forming a silky indumentum that characterizes leaf surfaces in $P$. leucopolitana (Fig. 7) and $P$. leucopolitana $\times P$. incana (Fig. 8), sometimes sparsely in P. collina (Fig. 3), $P$. thyrsiflora (Fig. 5) and P. wimanniana (Fig. 6), whereas on the lower surfaces they are restricted to the veins. They are usually present also on stipules, sepals and epicalyx segments.

TABLE 1. Hair types found in Polish selected taxa of $P$. subsect. Collinae.

\begin{tabular}{|c|c|c|c|c|c|c|c|c|c|c|}
\hline \multirow{2}{*}{ Taxa } & \multicolumn{5}{|c|}{ Apper leaf surface } & \multicolumn{5}{|c|}{ Lower leaf surface } \\
\hline & Straight & Imvoluted & Curved & Crispate & Stellate & Straight & Involuted & Curved & Crispate & Stellate \\
\hline P. collina & + & - & + & + & + & + & - & + & + & + \\
\hline P. silesiaca & + & - & - & - & + & + & - & + & + & + \\
\hline P. thyrsiflora & + & + & - & - & + & + & - & + & + & + \\
\hline P. wimanniana & + & - & + & + & + & + & - & + & + & - \\
\hline P. leucopolitana & + & - & + & + & + & + & - & + & + & - \\
\hline$P$. leucopolitana $\times P$. incana & + & - & + & + & + & + & - & + & + & - \\
\hline
\end{tabular}
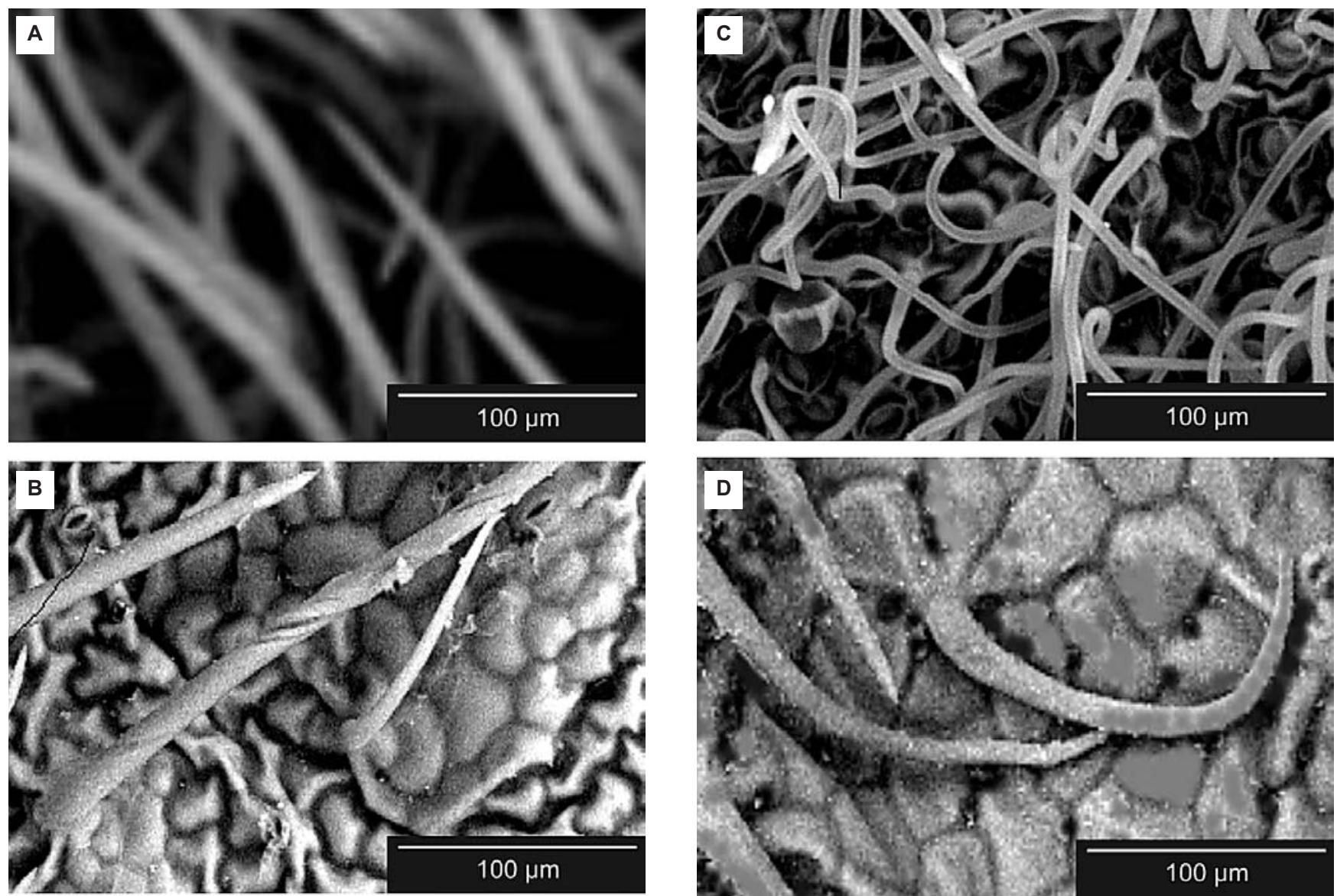

Fig. 1. (SEM). Hair types of $P$. subsect. Collinae, $\times 1000$ : [A] straight hairs with smooth surfaces, $P$. leucopolitana; [B] involuted hairs, upper leaf surface, $P$. thyrsiflora $; \mathrm{C}]$ irregularly crispate hairs, lower leaf surface, $P$. collina s.str.; [D] curved hairs, upper leaf surface, $P$. wimanniana. 

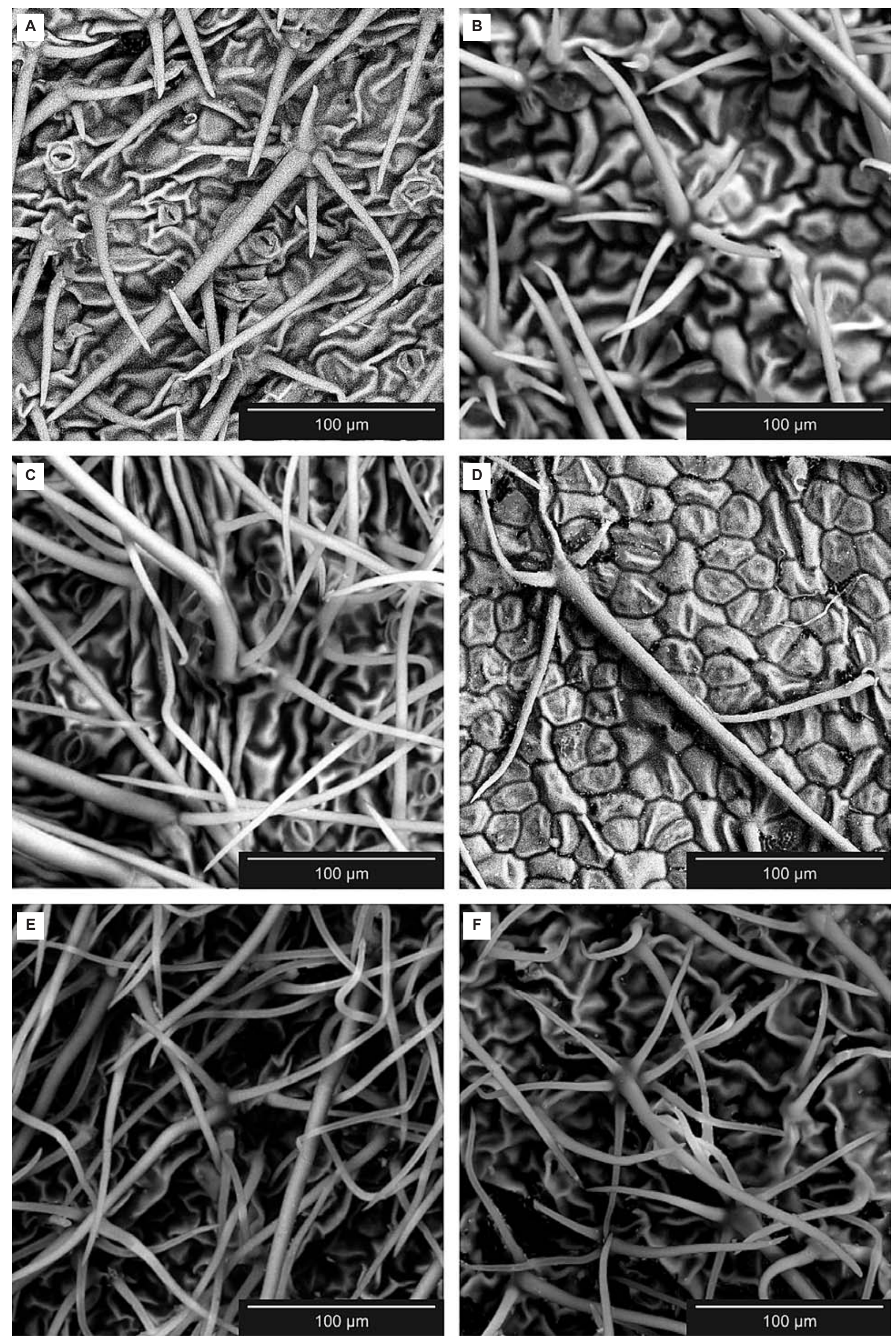

Fig. 2. (SEM). Stellate hairs $\times 1000:[\mathrm{A}]$ P. collina s.str., $[\mathrm{B}]$ P. silesiaca, $[\mathrm{C}]$ P. thyrsiflora, $[\mathrm{D}]$ P. wimanniana, $[\mathrm{E}]$ P. leucopolitana, $[\mathrm{F}] P$. leucopolitana 

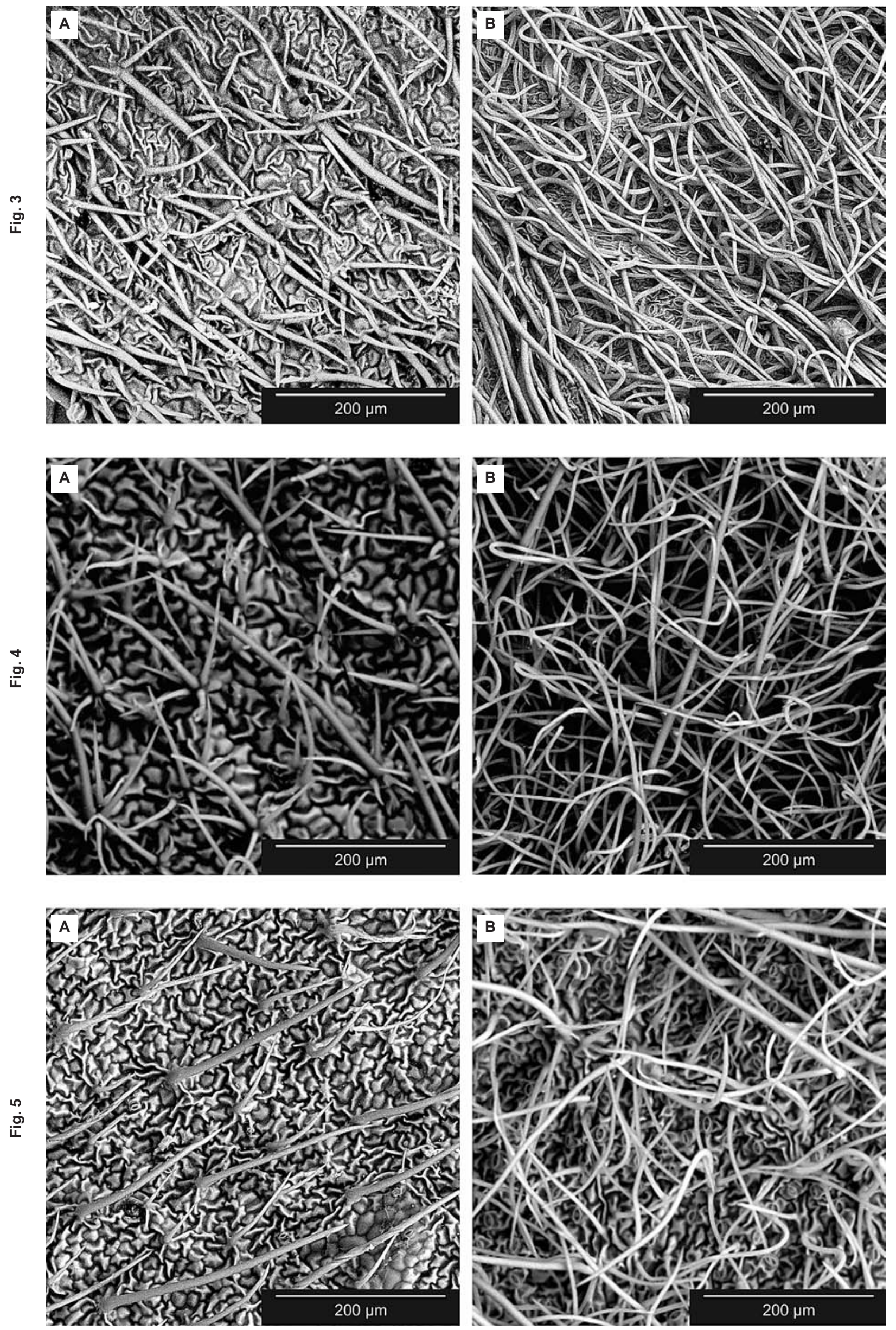

Figs 3-8. (SEM). Lower $[\mathrm{A}] \times 500$ and upper $[\mathrm{B}] \times 500$ leaf surface of $P$. subsect. Collinae: Fig. 3. P. collina s.str.; Fig. 4. P. silesiaca; Fig. 5. P. thyrsiflora. 

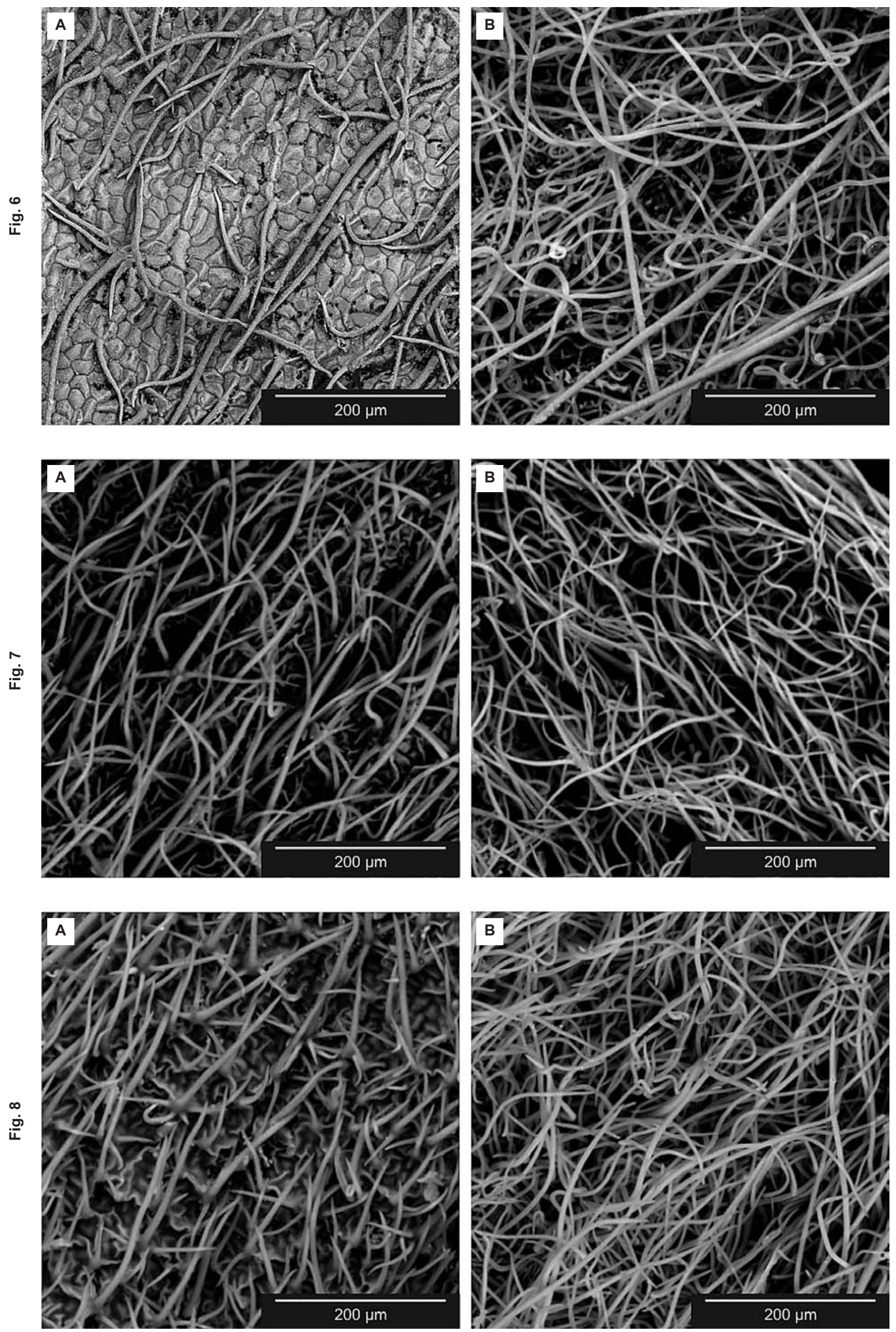

Figs 3-8. (SEM). Lower $[\mathrm{A}] \times 500$ and upper $[\mathrm{B}] \times 500$ leaf surface of $P$. subsect. Collinae: Fig. 6. P. wimanniana; Fig. 7. P. leucopolitana; Fig. 8. P. leucopolitana $\times$ P. incana. 


\section{Involuted hairs (Fig. 1B)}

Involuted hairs are unicellular hairs vary in length from $50 \mu \mathrm{m}$ to $150 \mu \mathrm{m}$. They are in a corkscrew-like fashion, often appressed to the surface. The involuted hairs sparsely occur on the upper leaf surface in P. thyrsiflora (Fig. 5A).

\section{Crispate hairs (Fig. 1C)}

Crispate hairs are unicellular, and less than $1 \mathrm{~mm}$ long. The hairs are usually terete and entangled in a cotton woollike fashion so that it is impossible to tell where a single hair begins or ends. They are raised from the surface. The hairs are usually present on all leaf parts and may be found also on stems, inflorescence axes, sepals and epicalyx segments. The crispate hairs are common on the leaves among the taxa examined, sometimes as the dominating indumentum, sometimes sparsely and intermingled with other hair types. They form a tomentum on the lower leaf surface in P. collina s.str (Fig. 3B).

\section{Curved hairs (Fig. 1D)}

Curved hairs are unicellular and less than a millimeter long. They are appressed to the surface. The curved hairs are common on lower leaf surface and may be found also on stipules, petiole, sepals and epicalyx segments, whereas they are much rarer on upper surfaces (Table 1).

\section{Stellate hairs (Fig. 2A-F)}

These are by definition unicellular star-like hairs, having a variable number of arms (3-7) radiating from a large basal cell; longer arm from $120.7 \mu \mathrm{m}$ in P. silesiaca (Fig. 2B) to $364.3 \mu \mathrm{m}$ in $P$. wimanniana (Fig. 2D), protruding from the surface; shorter arms from $53 \mu \mathrm{m}$ in $P$. silesiaca (Fig. 2B) to 204 in $P$. thyrsiflora (Fig. 2C), parallel to the surface (Table 2). They are usually present on all leaf parts and may be found also on stipules, petiole, sepals and epicalyx segments.

Individual types of hairs do not occur separately on the plant, but in a combination with others. The length of hairs, their direction, density and the predominant hair type all determine the aspect and condition of the whole indumentum.

\section{DISCUSSION}

The macromorphological division of $P$. collina group proposed by Wolf (1908) based on the type of stylus, type of leaf division and position of the floriferous stems agrees with the type of hairs.

The variety of hair types found (Wolf 1908; Pedersen 1964; Rousi 1965; Soják 1986, 1995; Eriksen 1997; Eri- ksen and Yurtsew 1999) in the genus Potentilla seems to be well represented within the $P$. subsect. Collinae.

The present observations have confirmed previous descriptions by other authors (Wolf 1908; Leht 1990; Soják 1995; Gerstberger 2002) who stated that three types of hairs: crispate, straight and stellate, occur on leaves, but also on the stem, stipules, sepals and epicalyx segments. Crispate hairs occur on leaves of all of investigated taxa, but only on the underside of $P$. collina leaves they form a conspicuous greyish-white tomentum. Contrary to literature data, no tomentum was found to occur on leaves of the remaining taxa, i.e. $P$. silesiaca (Fig. 4), P. thyrsiflora (Fig. 5), $P$. wimanniana (Fig. 6), P. leucopolitana (Fig. 7) and $P$. leucopolitana $\times P$. incana (Fig. 8). The crispate hairs in these taxa are not as numerous and dense as in $P$. collina s.str. and they are covered by the more abundantly occurring silvery-white straight hairs.

Curved hairs (Fig. 1D) have not hitherto been mentioned in descriptions of indumentum for taxa from the $P$. subsect. Collinae. Their occurrence was recorded on the underside of leaves for all investigated taxa and on the upper side of leaves of $P$. collina s.str., $P$. leucopolitana and $P$. leucopolitana $\times P$. incana (Table 1). These airs due to their sparse occurrence in small numbers do not significantly influence the overall aspect of leaf indumentum. Their shape is similar to that of hairs which cover $P$. tabernaemontani leaves.

My observations made with the use of SEM have shown that stellate hairs do not occur exclusively on the leaves of P. collina (Petunnikov 1895) and P. silesiaca (Wolf 1908), but also on the leaves of $P$. thyrsiflora, $P$. wimanniana, $P$. leucopolitana and $P$. leucopolitana $\times P$. incana. This study shows marked differences in density, position, as well as in the size and number of arms of stellate hairs. Such conspicuous differences in the architecture of stellate hairs have not been reported in the literature earlier. Stellate hairs are difficult to see without a stereo microscope.

The hair type is a very good character for indentifying taxonomically complicated taxa.

The best characteristics for distinguishing $P$. collina s.str. from $P$. argentea L. concern their leaflets: the leaflets of $P$. collina are thin, with margins slightly rolled down, the indumentum is made up of hairs of 4 types; the leaves of $P$. argente $a$ are thicker, with margins rolled down, densely tomentose beneath, sparsely pubescent to densely white-tomentose above, stellate hairs absent.

Potentilla incana, $P$. Xsubarenaria and $P$. leucopolitana $\times P$. incana can be distinguished easily from each other using a magnifying glass. Leaves of $P$. incana are covered with stellate hairs mixed with long hairs which make the plant greyish; $P$. $\times$ subarenaria, which is considered to be

TABLE 2. Measurements of stellate hairs in Polish selected taxa of $P$. subsect. Collinae: average \pm confidence limits of arms for all taxa studied; all values in $\mu \mathrm{m}$.

\begin{tabular}{|c|c|c|c|c|c|c|}
\hline \multirow{2}{*}{ Taxa } & \multirow{2}{*}{$\begin{array}{l}\text { Number } \\
\text { of arms }\end{array}$} & \multicolumn{2}{|c|}{ Longer arm } & \multicolumn{2}{|c|}{ Shorter arm } & \multirow{2}{*}{$\begin{array}{l}\text { Longer/shorter } \\
\text { arm ratio }\end{array}$} \\
\hline & & Length & Thickness & Length & Thickness & \\
\hline P. collina & $(3)-5$ & $218.1 \pm 14.32$ & $13.3 \pm 0.05$ & $76.5 \pm 8.16$ & $8.4 \pm 0.03$ & 2.9 \\
\hline P. silesiaca & 5 & $120.7 \pm 14.8$ & $12.1 \pm 0.04$ & $53 \pm 6.11$ & $8.3 \pm 0.02$ & 2.3 \\
\hline P. thyrsiflora & $(3)-5$ & $219.1 \pm 30.01$ & $12.8 \pm 0.03$ & $204 \pm 28.32$ & $6.9 \pm 0.01$ & 1.1 \\
\hline P. wimanniana & (3)-5 & $364.3 \pm 16.42$ & $12 \pm 0.07$ & $84.5 \pm 8.21$ & $7.2 \pm 0.03$ & 4.3 \\
\hline P. leucopolitana & (3) -5 & $203.4 \pm 21.15$ & $9.8 \pm 0.04$ & $134.5 \pm 10.52$ & $7.6 \pm 0.02$ & 1.5 \\
\hline$P$. leucopolitana $\times P$. incana & 7 & $182.9 \pm 11.67$ & $15.2 \pm 0.06$ & $60.2 \pm 7.05$ & $6.9 \pm 0.02$ & 3 \\
\hline
\end{tabular}


of hybrid origin $(P$. incana $\times$ tabernaemontani), has curved and stellate hairs on the surface. The stellate hairs of $P$. incana, which were described by Wolf (1908) as "Sternhaare", may consist of up to 30 identically long rays, while those of $P$. $\times$ subarenaria have about 10 or less identically rays. Leaflets of $P$. leucopolitana $\times P$. incana are covered with straight hairs mixed with stellate hairs which make the leaves sparsely sericeous hairy; the stellate hairs ("Zackenhaare") consist of up to 7 not identically long arms.

The difference in the amount of hairiness is quite conspicuous between the taxa from $P$. subsect. Collinae, justifying the diagnostic use of this characteristic in such cases. Hairiness of the petiole, sepals and epicalyx segments was usually correlated with the hairiness of the upper surface of the leaves.

These features of indumentum in addition to the anatomy of leaves (Kołodziejek and Gabara 2003) and morphology of achenes (Kołodziejek and Gabara 2007) proved to be of high systematic importance in taxonomy of $P$. subsect. Collinae.

\section{KEY TO THE STUDIED TAXA BASED} ON DIFFERENT KINDS OF HAIRS

1. Leaflets sericeous hairy on both sides, i.e. with long, silky hairs, usually appressed to the surface.....

1. Leaflets grey or greyish-white with sparse straight hairs3

2. Leaflets densely whitely sericeous hairy with relatively sparse stellate hairs: stellate hairs with (3)5 arms: ratio of longer to shorter arm is 1.5 .........P. leucopolitana P.J. Müller

2. Leaflets sparsely sericeous hairy with numerous stellate hairs; stellate hairs with 7 arms: ratio of longer to shorter arm is 3 ...P. leucopolitana P.J. Müller $\times P$. incana $\mathrm{P}$. Gaertner

3. Leaflets greyish-white or sericeous; lower surface of leaflets with straight or slightly curved hairs, or stellate hairs .

3. Leaflets grey or greyish-white with relatively sparse stellate hairs

4. Leaflets with sparse stellate hairs with (3)5 arms on both surfaces: longer arms of stellate hairs about 2.9 times longer than shorter arms; lower surface of leaflets with densely crispate hairs, usually \pm tomentose.......P. collina Wibel

4. Leaflets with many stellate hairs with 5 arms on both surfaces: longer arms of stellate hairs about 2.3 times longer than shorter arms; lower surface with sparse crispate hairs; tomentum absent............P. silesiaca Uechtr.

5. Leaflets green on both surfaces, the indumentum not completely covering the surface; upper leaf surface with many straight hairs, longer arms (ca. $219 \mu \mathrm{m})$ of stellate hairs less than 4 times longer than shorter arms (ca. 204 $\mu \mathrm{m})$...... $P$. thyrsiflora Hülsen ex Zimmeter

5. Leaflets grayish-green on both surfaces; the indumentum completely covering the surface; stellate hairs present on upper surface, longer arms (ca. $364 \mu \mathrm{m}$ ) of stellate hairs more than 4 times as long as shorter arms (ca. $84 \mu \mathrm{m}$ ); crispate hairs absent .P. wimanniana Günther and Schummel

\section{ACKNOWLEDGEMENTS}

I would like to thank the Curators of herbaria for making available the material of Potentilla, and most of all Dr. Alexander Sennikov (V.L. Komarov Botanical Institute, Saint-Petersburg), Dr. Somlyay Lajos (Hungarian Natural History Museum in Budapest) and Dr. Jiři Soják (Institute of Botany, Academy of Sciences Czech Republic, Pruhonice) for lending the $P$. collina Wibel, $P$. leucopolitana P.J. Müller, $P$. thyrsiflora Hülsen ex Zimmeter, $P$. silesiaca Uechtr. and $P$. wimanniana Günther and Schummel. Finally, I would like to thank Dr. Krzysztof Polański (Institute of Physics, University of Lodz) for taking the photographs.

Part of this work was supported by grant No. 2 P04F 040 26 from the Ministry of Science and Information Society Technologies (KBN).

LIST OF TAXA EXAMINED

AND THEIR VOUCHER SPECIMENS:

P. collina Wibel s.str. (from type) - Wertheim, 1799, A. Wibel (LE 2174); P. thyrsiflora Hülsen ex Zimmeter - Kleparów bei Lemberg (Ukraine), 1885, B. Błocki (BP 167319); P. silesiaca Uechtr. - Dolny Śląsk prov., Ostra Góra, between Miękinia and Mrozów (Breslau: Spitzberg, zwischen Nimkau und Nippern) loc. class. 28.06.1863, R. Uechtritz (PRA); P. wimanniana Günther et Schummel (from typus) - Scheitnich, Pepelwitz, Friedewalde, Wimann 1813 (LE); P. leucopolitana P.J. Müller (from type) - F. Schultz Herbarium normale Cent. 3 no. 256, 27.5.1857, Wissenbourg (Bas-Rhin, France); F. Schultz (BP 165401); Jaroszów (region of Silesia-Cracow) N50³9'21'N/19 21'32'"E, 315 m a.s.1., xerothermic grassland, 28.5.2003, J. Kołodziejek (LOD).

\section{LITERATURE CITED}

ERIKSEN B. 1997. Morphometric analysis of Alaskan members of the genus Potentilla sect. Niveae (Rosaceae). Nordic J. Bot. 17: 621-630.

ERIKSEN B., YURTSEV B.A. 1999. Hair types in Potentilla sect. Niveae - terminology and systematic distribution. In: I. Nordal and V. Yu. Razzhivin (eds): The species concept in the High North - A Panarctic Flora initiative. Det Norske Videnskaps - Akademi. I. Mat. Naturv. Klasse, Skrifter, Ny ser. 38: 201-221.

GERSTBERGER P. 2002. 26. Potentilla L. In: "Gustav Hegi Illustrierte Flora von Mitteleuropa“. Weber H.E. (ed.). Parey Buchverlag, Berlin 4 (2C): 109-205.

HOLMGREN P.K., HOLMGREN N.H., BARNETT L.C. 1990. Index Herbariorum. Part I: The Herbaria of the World. 8th. Edition. New York Botanical Garden, Bronx.

KOŁODZIEJEK J., GABARA B. 2003. Analiza morfologiczna $\mathrm{i}$ anatomiczna liści krajowych gatunków z grupy Potentilla collina s.1. (Rosaceae). Genus (Suppl.): 27-36. (in Polsh with English summary)

KOŁODZIEJEK J., GABARA B. 2007. Investigations of achenes in Potentilla collina group (Rosaceae). Acta Soc. Bot. Pol. 76 (1): 35-42.

KURTTO A., LAMPINEN R., JUNIKKA L. (eds). 2004. 13. Rosaceae (Spiraea to Fragaria, excl. Rubus). In: "Atlas Florae Europaeae. Distribution of Vascular Plants in Europe". Comm. Map. Flora Eur. Soc. Biol. Fenn. Van., Helsinki 13: 185-217. 
LEHT M. 1990. The genus Potentilla L. in the Baltic republics. Leaf epidermis. Proc. Estonian Acad. Sci. Biol. 38: 33-39. (in Russian with English summary)

MIREK Z., PIĘKOŚ-MIRKOWA H., ZAJĄC A., ZAJĄC M. 2002. Flowering plants and pteridophytes of Poland. A checklist. Krytyczna lista roślin naczyniowych Polski. Wyd. Instytutu Botaniki im. W. Szafera Polskiej Akademii Nauk, Kraków. Ser.: Różnorodność biologiczna Polski. Vol. 1: 129-130.

PEDERSEN A. 1964. Potentilla collina, Potentilla argentea og Potentilla subarenaria i Danmark. (Deut. Zusammenf.). Botanisk Tidsskrift 60: 90-98. (in Danish with German summary)

PETUNNIKOV A.N. 1895. Die Potentillen Centralrusslands. Acta Horti Potrop. 14 (1): 1-52.
ROUSI A. 1965. Biosystematic studies on the species aggregate Potentilla anserina L. Ann. Bot. Fenn. 2: 47-112.

SOJÁK J. 1986. Notes on Potentilla. I. Hybridogenous species derived from intersectional hybrids of sect. Niveae $\times$ sect. Multifidae. Botanische Jahrbücher für Systematik, Pflanzengeschichte und Pflanzengeographie 106: 145-210.

SOJÁK J. 1995. Potentilla L. In: "Flora of the Czech Republic". Slavik B. (ed.). Academia, Praha 4: 283-314. (in Czech)

SZAFER W., PAWŁOWSKI B. 1955. Potentilla L. In: "Flora polska. Rośliny naczyniowe Polski i ziem ościennych". Szafer W., Pawłowski B. (eds). PWN, Warszawa, 7: 96-143.

WOLF T. 1908. Monographiae der Gattung Potentilla L. Biblioth. Bot. 16: 1-714. 